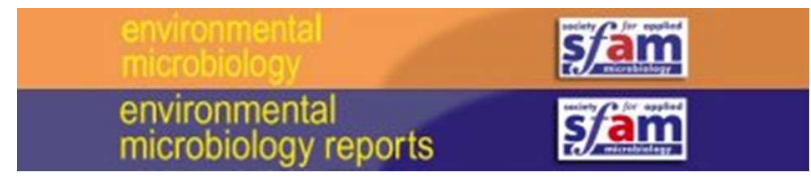

\title{
Biosynthetic genes and activity spectrum of antifungal polyynes from Collimonas fungivorans Ter331
}

\begin{tabular}{|r|l|}
\hline Journal: & Environmental Microbiology and Environmental Microbiology Reports \\
\hline Manuscript ID: & EMI-2013-1624 \\
\hline Manuscript Type: & EMI - Research article \\
\hline Journal: & Environmental Microbiology \\
\hline Date Submitted by the Author: & 23-Dec-2013 \\
\hline Complete List of Authors: & $\begin{array}{l}\text { Fritsche, Kathrin; NIOO-KNAW, Microbial Ecology } \\
\text { van den Berg, Marlies; NIOO-KNAW, Microbial Ecology } \\
\text { De Boer, Wietse; NIOO-KNAW, Microbial Ecology } \\
\text { van Beek, Teris; Wageningen University, Laboratory of Phytopathology } \\
\text { Raaijmakers, Jos; Wageningen University, Laboratory of Phytopathology } \\
\text { van Veen, Hans; NIOO-KNAW, Microbial Ecology } \\
\text { Leveau, Johan; University of California, Plant Pathology }\end{array}$ \\
\hline Keywords: & \begin{tabular}{l} 
bacteria, fungi, microbe:microbe interactions, functional diversity \\
\hline
\end{tabular} \\
\hline
\end{tabular}

\section{SCHOLARONE $^{\text {th }}$ \\ Manuscripts}


1 Biosynthetic genes and activity spectrum of antifungal polyynes from Collimonas

2 fungivorans Ter331

3

4 Kathrin Fritsche ${ }^{1,2}$, Marlies van den Berg ${ }^{1}$, Wietse de Boer ${ }^{1}$, Teris A. van Beek ${ }^{3}$, Jos M.

5 Raaijmakers ${ }^{4}$, Johannes A. van Veen $^{1,5}$, Johan H.J. Leveau ${ }^{1,6}$

6

$7{ }^{1}$ Department of Microbial Ecology, Netherlands Institute of Ecology (NIOO-KNAW),

8 Wageningen, The Netherlands

$9 \quad{ }^{2}$ BioDetection Systems b.v., Amsterdam, The Netherlands

$10{ }^{3}$ Laboratory of Organic Chemistry, Wageningen University, Wageningen, The Netherlands

$11{ }^{4}$ Laboratory of Phytopathology, Wageningen University, Wageningen, The Netherlands

$12{ }^{5}$ Institute of Biology, Leiden University, Leiden, The Netherlands

$13{ }^{6}$ Department of Plant Pathology, University of California, Davis, CA, USA

14

15

16

17 Running title: Characterization of Collimonas antifungal polyynes 18 


\section{ABSTRACT}

20 The antifungal activity of bacteria from the genus Collimonas has been well documented, but

21 the chemistry and gene functions that underlie this phenotype are still poorly understood.

22 Screening of a random plasposon insertion library of Collimonas fungivorans Ter331 for loss-

23 of-function mutants revealed the importance of gene cluster K, which is annotated to code for

24 the biosynthesis of a secondary metabolite and which features genes for fatty acid desaturases

25 and polyketide synthases. Mutants in gene cluster K had lost the ability to inhibit hyphal

26 growth of the fungus Aspergillus niger and were no longer able to produce and secrete several

27 metabolites that after extraction and partial purification from wildtype strain Ter331 were

28 shown to share a putative ene-triyne moiety. Some but not all of these metabolites were able

29 to inhibit growth of $A$. niger, indicating functional variation within this group of Collimonas-

30 produced polyyne-like 'collimomycins'. PCR analysis of isolates representing different

31 Collimonas species indicated that the possession of cluster $\mathrm{K}$ genes correlated positively with

32 antifungal ability, further strengthening the notion that this cluster is involved in

33 collimomycin production. We discuss our findings in the context of other bacterially

34 produced polyynes and the potential use of collimomycins for the control of harmful fungi. 


\section{INTRODUCTION}

37 The genus Collimonas (family Oxalobacteraceae, class Betaproteobacteria) consists of mostly

38 soil bacteria that are defined by their ability to grow at the expense of living fungal hyphae 39 under nutrient-limited conditions (de Boer et al., 2004; Leveau and Preston, 2008; Leveau et 40 al., 2010). So far, three species have been described: C. fungivorans, C. pratensis, and $C$. 41 arenae (Höppener-Ogawa et al., 2008). All three species have representatives for which 42 antifungal activity was demonstrated (Leveau et al. 2010; Mela et al., 2012), but the 43 metabolites involved in this activity have not yet been characterized. In a recent study by 44 Mela et al. (2011), it was shown that on nutrient-poor water agar plates the hyphal growth of 45 Aspergillus niger was inhibited by Collimonas fungivorans strain Ter331. This inhibition did

not require direct contact between the bacteria and the fungus, as it was not affected by physical separation of the two organisms by an $8-\mathrm{kDa}$ cut-off dialysis membrane (Fritsche et al., 2008). This suggested that the antifungal activity was due to a small, diffusible factor produced by the bacterium. In confrontation with $A$. niger, several genes putatively involved in the production of antifungal compound(s) were upregulated in C. fungivorans Ter331 (Mela et al., 2011). Using a comparative genomic hybridization approach (Mela et al., 2012), the same group of genes, designated as cluster $\mathrm{K}$, was found in its entirety on the genome of C. fungivorans Ter14, only partially in C. fungivorans Ter6, and not at all in C. pratensis Ter91 or C. arenae Ter10. This finding aligned well with the observation that $C$. fungivorans Ter331 and Ter14, but not C. fungivorans Ter6, C. pratensis Ter91 and C. arenae Ter10, inhibit growth of $A$. niger in a confrontation assay (Mela et al., 2012). The objective of the present study was to isolate and determine the bioactivity of the compound(s) responsible for the observed antifungal activity of $C$. fungivorans Ter331 against $A$. niger, to carry out preliminary research towards the chemical structure of these compounds, which we refer to 
60 here as collimomycins, and to identify the genes that underlie the antifungal phenotype of

$61 \quad$ Ter331.

62

RESULTS

64

On water-yeast agar supplemented with $2 \mathrm{mM} N$-acetylglucosamine (WYA-Nag), $C$. fungivorans Ter331 inhibited hyphal growth of $A$. niger and induced branching and hyphal

swelling (Figure 1). Similar antagonistic activity was observed against Aspergillus species westerdijkiae and versicolor, Penicillium species glabrum and chrysogenum (Figure S1), as well as Verticilium dahliae JR2 race 1 and the oomycete pathogens Saprolegnia parasitica and Phytophthora megakarya CSAKO (not shown). In contrast, growth of the phytopathogens Sclerotium rolfsii H001, Rhizoctonia solani, Fusarium oxysporum f. sp. asparagi, F. solani, Botrytis cinerea B05.10, Gaeumannomyces graminis, Geotrichum candidum, Alternaria brassicicola, Penicillium expansum and the oomycete Pythium ultimum was not inhibited by $C$. fungivorans Ter331 under these conditions.

We tested 36 other Collimonas strains in the confrontation assay with A. niger (Table 1). From this analysis, it became apparent that the antifungal activity was unique to members of C. fungivorans subgroup B, which includes Ter331 and which was defined previously (Höppener-Ogawa et al., 2008) based on BOX-PCR fingerprint patterns of 42 Collimonas isolates. Only two strains from this subgroup B (out of 14 strains tested) were unable to inhibit A. niger. As we will show below, these isolates (i.e. SO 30 and SO 115) also lacked one or more cluster $\mathrm{K}$ genes, suggesting the involvement of these genes in the fungistatic phenotype. None of the $C$. fungivorans subgroup $C$ strains $(\mathrm{n}=4)$, including $C$. fungivorans type strain Ter6, was active against $A$. niger, and neither were any of the tested $C$. arenae $(\mathrm{n}=4)$ or $C$. pratensis $(\mathrm{n}=15)$ strains. The non-collimonad control Pseudomonas protegens $\mathrm{Pf}$ 5 also did not inhibit hyphal growth of $A$. niger. 
Identification and genomic characterization of $C$. fungivorans mutants with reduced antifungal activity. We used WYA-Nag in a medium-throughput setup (see Experimental Procedures) to test a total of 3,300 random plasposon mutants of $C$. fungivorans Ter331 for reduced activity against $A$. niger. Six such mutants were identified and selected for further analysis. Two (8G9 and 13E12) were tested and confirmed to be impaired in halting the hyphal growth of not only $A$. niger but also all other fungi and oomycetes whose growth was affected negatively by wildtype $C$. fungivorans Ter331 under the same conditions (Figure S1).

93 In three mutants $(10 \mathrm{E} 11,14 \mathrm{C} 11$, and $14 \mathrm{G} 4)$, the plasposon insertions were mapped to genes involved in amino acid biosynthesis. Mutant 10E11 carried the plasposon in gene Cf_2563 (CFU_2502) which codes for the large chain of carbamoyl-phosphate (CP) synthetase, an enzyme that provides $\mathrm{CP}$ as precursor for the biosynthesis of arginine and pyrimidine (Holden et al., 1999). In mutant 14G4, the plasposon insertion was positioned in gene Cf_3833 (CFU_3751) which codes for 5-enolpyruvylshikimate-3-phosphate synthase, the penultimate enzyme in the shikimate pathway. The end-product of this pathway is chorismate, which serves as substrate for the biosynthetic pathway of the aromatic amino acids phenylalanine, tyrosine and tryptophan (Herrmann, 1999). In mutant 14C11, the plasposon localized to gene Cf_752 (CFU_0701) which codes for the amidotransferase component of anthranilate synthase, an enzyme that converts chorismate to anthranilate as part of the tryptophan

104 biosynthetic pathway.

105 For the other three mutants $(8 \mathrm{G} 9,13 \mathrm{E} 12,28 \mathrm{~A} 12)$, plasposon insertion sites were located in 106 proximity to each other and within or close to the previously identified gene cluster K (Mela 107 et al., 2011) on the Ter331 genome (Figure 2). Genes in this cluster (Cf_1128-1142; Table 108 S1) were previously shown to be upregulated in confrontation of C. fungivorans Ter 331 with 109 A. niger (Mela et al., 2011). The insertion in mutant 13E2 disrupted gene Cf_1135, which 
110 codes for a protein annotated as a fatty acid CoA ligase. Cf_1135 is the first gene in a

111 predicted operon of seven, with three genes (Cf_1134, Cf_1133, and Cf_1131) coding for

112 fatty acid desaturases. In this operon, gene Cf_1132 is predicted to code for a putative acyl

113 carrier protein (ACP), Cf_1130 for a hydrolase, and Cf_1129 for a rubredoxin-type protein.

114 In mutant 8G9, the plasposon insertion was located upstream of Cf_1141, which encodes a 3-

115 oxoacyl ACP synthase, and within gene Cf_1143, which codes for a LysR-type regulator and

116 forms a predicted operon with gene Cf_1144, annotated as coding for a Major Facilitator

117 Superfamily (MFS) transporter. The latter showed resemblance to another MFS protein

118 encoded by cluster K, i.e. the predicted product of gene Cf_1136. This gene was annotated as

119 coding for a drug resistance transporter, with similarity to FarB of Neisseria gonorrhoea,

120 which has been shown to confer resistance against antibacterial fatty acids (Lee and Shafer,

121 1999). Cf_1136 forms a predicted operon with three other genes, coding for a fatty acid

122 desaturase (Cf_1139), a Rieske-type oxygenase (Cf_1138), and a hypothetical protein

123 (Cf_1137), respectively. In mutant 28A12, the plasposon was located upstream of gene

124 Cf_1145a, which codes for yet another fatty acid desaturase and forms a predicted operon

125 with gene Cf_1145 with unknown function.

126 The content and synteny of gene cluster $\mathrm{K}$ and its flanking regions appeared to be conserved

127 to various degrees in several other bacterial genomes (Figure 2B). In Burkholderia

128 vietnamiensis G4, Burkholderia sp. KJ006, and Burkholderia ambifaria IOP40-10 and

129 MEX5, we found a near-complete orthologous version of cluster K. Only part of the cluster

130 (Cf_1135-Cf_1141) was identified in the genomes of Burkholderia gladioli BSR3,

131 Streptomyces sp. Mg1 (accession number DS570401) and Pseudomonas protegens Pf-5

132 (Paulsen et al., 2005; Loper et al., 2012) and P. protegens CHA0. In the two Pseudomonas

133 genomes, the Cf_1131 and Cf_1130 orthologs occur fused into a single gene. P. protegens Pf-

1345 is well-known for its antifungal activity (Loper and Gross, 2007). Recently (Hassan et al., 
135 2010), genes PFL_0261-0268 of Pf-5 (orthologous to Cf_1135-1129) were identified as

136 belonging to a novel orphan gene cluster for which the metabolic product, designated 137 compound $\mathrm{B}$, is yet unknown.

138 To further substantiate the claim that cluster $\mathrm{K}$ genes are involved in the antifungal activity of

139 Collimonas, we designed and used degenerate primers to amplify and detect orthologs of 140 genes Cf_1133, Cf_1138, Cf_1139, and Cf_1141 in the genomes of our Collimonas culture 141 collection. The results of the PCR analysis are presented in Table 1. The possession of all four 142 genes correlated perfectly with the ability of Collimonas strains to inhibit $A$. niger in a 143 confrontation assay. Conversely, the absence of one or more of these four genes (i.e. in $C$. 144 fungivorans subgroup B strains SO 30 and 115, in all C. fungivorans subgroup C strains, and 145 in all C. arenae and C. pratensis strains) correlated with the inability to inhibit $A$. niger. As 146 expected from its genomic context (Figure 2), the non-collimonad control strain P. protegens 147 Pf-5 carried an ortholog of Cf_1133, but not Cf_1138, Cf_1139, or Cf_1141. It was also not 148 inhibitory towards $A$. niger (Table 1). In these respects, Pf-5 mimicked strains of $C$. 149 fungivorans subgroup C, further suggesting the importance of Cf_1138, Cf_1139, and/or 150 Cf_1141 for antifungal activity of Ter331 and other C. fungivorans subgroup B strains.

152 Extraction of collimomycin(s). Extracts from WYA-Nag agar on which C. fungivorans 153 Ter331 was grown were inhibitory to hyphal growth of $A$. niger, whereas extracts from 154 mutants 8G9, 13E12, and 28A12 grown under the same conditions were not (Figure 3). 155 Analysis by Reversed-Phase High-Performance Liquid Chromatography (RP-HPLC) with 156 Diode-Array-Detection revealed the presence of specific peaks in the extracts from $C$. 157 fungivorans Ter331, which were absent in the extracts obtained from mutant 13E12 (Figure 158 4A) or mutant 28A12 (Figure S2). RP-HPLC fractions of wildtype Ter331 and mutant 13E12 159 extracts were collected, concentrated and tested for activity against A. niger. None of the 
160 13E12 fractions showed antifungal activity, whereas two out of seven fractions of Ter331 did

161 (Figure 4B). By adopting a different elution gradient, a higher resolution of peaks was

162 obtained (Figure 5), and all five fractions containing one or more of the major peaks (a-h)

163 showed a highly characteristic sawtooth-shaped UV spectrum. With the mutant extracts, no

164 such spectral patterns were ever found (not shown). This type of pattern is characteristic for

165 polyynes, which are polyacetylenic compounds with alternating triple and single carbon-

166 carbon bonds (Bohlmann et al., 1973). The observed UV spectral peaks $(\lambda 327 / 328,306 / 307$,

$167287 / 288,271,240 / 241,229 / 230 \mathrm{~nm}$ ) closely resembled those of compounds that contain an

168 ene-triyne moiety ( $-\mathrm{C}=\mathrm{C}-\mathrm{C} \equiv \mathrm{C}-\mathrm{C} \equiv \mathrm{C}-\mathrm{C} \equiv \mathrm{C}-$ ), according to Bohlmann et al. (1973) (i.e. $\lambda$ 328,

$169307,288,271,242$, and $231 \mathrm{~nm}$ ). While all five fractions showed this UV spectrum (Figure

170 5B), only two were shown to be active against $A$. niger, namely fraction 3 (Figure 5B, marked

171 with *, includes peaks $\mathrm{c}$ and $\mathrm{d}$ ) and fraction 5 (Figure 5B, marked with *, includes peaks $\mathrm{f}, \mathrm{g}$ 172 and $h)$.

\section{DISCUSSION}

175 The only antimicrobial compound described to date for the genus Collimonas is violacein

176 (Hakvag et al., 2009). Production of this purple pigment has been demonstrated for several

177 other members of the Oxalobacteraceae and is believed to provide protection against

178 protozoan predation (Matz et al., 2004). Here, we report the isolation, separation, and partial

179 characterization of a class of metabolites from C. fungivorans Ter331, some of which show

180 antifungal activity. These metabolites, which we collectively refer to as collimomycins,

181 shared a characteristically shaped UV spectrum suggesting an ene-triyne-based moiety, i.e.

182 featuring multiple conjugated $\mathrm{C} \equiv \mathrm{C}$ bonds. Such acetylenic compounds occur in a wide

183 structural variety in nature and their production has been described for plants, fungi, marine

184 sponges, and bacteria (Dembitsky, 2006; Minto and Blacklock, 2007; Abraham, 2010). Many 
185 have bioactive properties, such as antibacterial, cytotoxic, herbicidal and/or antifungal 186 activities (Abraham, 2010; Shi Shun and Tykwinski, 2006). The best studied bacterial 187 polyynes so far are the ene-diyne antitumor antibiotics from actinomycetes, e.g. calicheamicin 188 from Micromonospora echinospora sp. calichensis (Ahlert et al., 2002; Belecki et al., 2009).

189 Other examples of bacterially produced polyynes are cepacin A and B from Burkholderia 190 cepacia (Parker et al.,1984) and caryoynencin A-C from Burkholderia caryophylli (Kusumi et 191 al., 1987; Yamagucchi et al., 1995). The predicted UV maxima for cepacins (226, 236, 294, $192309 \mathrm{~nm})$ and caryoynencins (273, 290, 311, 331, 356, $382 \mathrm{~nm})$, based on Bohlmann (1973), 193 are different from those that we observed for collimomycins, suggesting that the latter 194 represent a structure that is different from that of previously described bacterial polyynes. 195 Initial attempts at purifying individual ene-triynes by means of semi-preparative HPLC failed 196 due to the extreme instability of these metabolites. This behavior has also been observed by 197 others (Parish et al., 2004). However by means of LC-MS it was possible to derive a 198 molecular weight for compounds b and d (Fig. 5) of 286 and 274 Da, respectively. The MS 199 data of the other peaks did not allow for an unambiguous determination of the molecular weight, most likely due to decomposition, poor ionization and/or in-source fragmentation.

201 The mode of action of polyacetylenes is still poorly understood. It has been suggested 202 (Dembitsky, 2006) that their cytotoxicity is related to membrane damage. This would be in 203 line with the observation that $A$. niger responds to the presence of $C$. fungivorans Ter331 by 204 upregulation of several genes involved in membrane fluidity (Mela et al., 2011). It would also 205 be consistent with the observation (Figure 1) that Collimonas induced Aspergillus 206 hyperbranching, which has been linked to membrane integrity (Lin and Momany, 2004). For 207 the actinomycete-produced antifungal polyyne L-660,631, the mode of action in Candida 208 albicans was demonstrated to be inhibition of ergosterol biosynthesis (Onishi et al., 2006). 209 Ergosterol is an essential component of fungal membranes and its biosynthesis represents an 
210 attractive and selective target for the development of novel fungicides. In confrontation with

211 C. fungivorans Ter331, one of the genes upregulated in A. niger was An03g00580 (Mela et

212 al., 2011), which codes for a key enzyme in the biosynthesis of ergosterol (van den Brink et

213 al., 1998). This might suggest that in A. niger, the membrane is a direct or indirect target of

214 collimomycins produced by $C$. fungivorans Ter331. However, we cannot rule out other or

215 additional targets, especially because we observed activity against oomycetes (Figure S1),

216 which are not known to feature ergosterol in their membranes.

217 The data in Figure 5 seem to suggest that the putative polyyne moiety alone is not sufficient

218 for collimomycin activity, as several fractions featuring the same characteristic UV spectrum

219 did not inhibit the growth of $A$. niger. The bioactivity of polyynes has been attributed in part

220 to the reactivity of the triple bonds that these compounds possess (Abraham, 2010). Indeed,

221 Yamaguchi et al. (1995) demonstrated that triyne and diyne analogs of dienetetraynic

222 caryoynencins were less active as antifungals compared to the tetrayne analog. However, the

223 type of accessory groups at one or both sides of the polyyne backbone also contributes to

224 bioactivity. For example, antimycobacterial activity of falcarindiol varied with alterations to

225 one or both terminal groups while leaving the diyne backbone intact (Deng et al., 2008). We

226 hypothesize that $C$. fungivorans Ter331 produces several different compounds which share a

227 putative ene-triyne feature but differ in the remaining part of the molecule. Future efforts

228 aimed at elucidating the structure of active as well as inactive collimomycins have to

229 overcome the inherent instability of these ene-triynes (Parish et al., 2004). An adapted

230 isolation and purification protocol, avoiding light, oxygen, and evaporation as much as

231 possible, followed by LC-MS and LC-NMR will unravel the chemistry that is important for

232 their activity.

233 For many polyynes, the genetics underlying their biosynthesis are unknown. Here, we

234 presented strong experimental evidence for the involvement of cluster $\mathrm{K}$ genes in the 
235 production of collimomycins by $C$. fungivorans Ter331. This cluster $\mathrm{K}$ features an 236 overrepresentation of genes coding for putative fatty acid desaturases (Table S1, Figure 2).

237 Such enzymes are often implicated in the polyyne biosynthesis. For example, in soldier 238 beetles, monounsaturated oleic acid is converted in five steps by three desaturases into the 239 immediate precursor of the polyacetylenic compound dihydromatricaria acid (Haritos et al., 240 2012). One of the genes in cluster $K$ (i.e. Cf_1132) is predicted to code for a 241 phosphopantetheine-binding protein of the type that is often found associated as a module 242 within polyketide synthase (PKS) gene clusters, and so perhaps this protein is involved in the 243 biosynthesis of the putative ene-triyne core (Minto and Blacklock, 2008), or in the process of 244 decorating one or both ends of the putative ene-triyne backbone of collimomycins.

245 Elucidation of the structure of the various collimomycins will allow a more precise mapping 246 of cluster $\mathrm{K}$ genes onto its biosynthetic pathway. We hypothesize that this pathway also 247 features carbamoyl-phosphate or intermediates/products of the shikimate pathway, based on 248 the observed inability of $C$. fungivorans Ter331 mutants 10E11, 14C11, and 14G4 to produce 249 collimomycins. The putative transporter genes found in cluster K (Cf_1136 and Cf_1144) 250 may represent an adaptation by $C$. fungivorans Ter331 to transport collimomycins outside of 251 the cell, possibly as part of a resistance mechanism.

252 In summary, the results presented here indicate that $C$. fungivorans Ter331 produces 253 antifungal compounds (collimomycins) that likely belong to the class of the polyynes. By a 254 combinatorial approach using mutant library screening for loss-of-function mutants and RP255 HPLC analysis of agar extracts from wild type and mutants, the production of collimomycins 256 could be linked to a cluster of genes involved in the biosynthesis of these compounds. We 257 found a positive correlation between the possession of these genes and ability to inhibit the 258 fungus Aspergillus niger. The polyynes released by C. fungivorans Ter331 inhibited the 
259 growth of several food spoiling and plant pathogenic fungi and are also active against 260 oomycetes harmful to fish or plants.

\section{EXPERIMENTAL PROCEDURES}

263 Microorganisms and culture conditions. C. fungivorans Ter331 (de Boer et al., 2004) was

264 originally isolated from a coastal dune site on the island of Terschelling, The Netherlands. 265 Strain Ter331R3 is a spontaneous rifampicin-resistant derivative of Ter331 that was 266 previously used (Leveau et al., 2006) to generate a genome-wide random mutant library with 267 plasposon pTnMod-KmOlacZ (Dennis and Zylstra, 1998). Ter331R3 was grown on King’s B 268 agar (KB) containing $40 \mu \mathrm{g}$ rifampicin (Rif) per ml, while plasposon mutants were selected 269 and grown on KB Rif supplemented with kanamycin $(50 \mu \mathrm{g}$ per ml). Other collimonads used 270 in this study have been described previously (Höppener-Ogawa et al., 2008). Pseudomonas 271 protegens Pf-5 (Loper et al., 2012) was used as a control in some experiments. The fungi used 272 in this study included Aspergillus niger N402 (Bos et al., 1988; ATCC 64974), $A$. 273 westerdijkiae CBS 112803, A. versicolor CBS 117.34, Penicillium chrysogenum CBS 306.48, 274 P. glabrum CBS 328.48, and P. expansum CBS 112450. Fungal spores were produced by 275 culturing the fungi on half-strength potato dextrose agar (PDA; Oxoid, Basingstoke, UK) for 2764 days at $30^{\circ} \mathrm{C}$. Spores were collected as described previously (Mela et al., 2011).

278 Agar plate confrontation assays. Confrontation assays between C. fungivorans Ter331 (or 279 other Collimonas strains) and A. niger (or other fungi) were performed on water yeast agar 280 (WYA) (Mela et al., 2011) supplemented with $2 \mathrm{mM} \mathrm{N}$-acetylglucosamine. Collimonas was 281 line-inoculated in the middle of the plate (Figure 1). Ten microliters of a suspension of $10^{4} \mathrm{~A}$. 282 niger spores per $\mathrm{ml}$ in $0.9 \% \mathrm{NaCl}$ were spot-inoculated at a distance of $2 \mathrm{~cm}$ from this 
283 Collimonas line. In a variation on this protocol, we substituted spores with agar plugs from

284 fungal cultures on half-strength PDA to inoculate the confrontation plates.

285

286

287

288

289

290

291

292

293

294

295

296

297

298

299

300

301

302

303

304

305

306

Screening for Collimonas mutants with reduced antifungal activity. Screening of the $C$. fungivorans Ter331 plasposon library (Leveau et al., 2006) for mutants with diminished antifungal activity towards $A$. niger was performed in bottomless 96-well-microtiter plates (Greiner Bio-One B.V., Alphen a/d Rijn, NL). To set up the assay, the bottom of the plates was sealed temporarily with sealing mats (Greiner Bio-One B.V.) to allow each well to be filled with $190 \mu \mathrm{l}$ WYA containing $2 \mathrm{mM} \mathrm{N}$-acetylglucosamine and $20 \mu \mathrm{g}$ of the $\mathrm{pH}$-indicator bromocresol purple per ml. After removal of the sealing mat, the agar in each well was inoculated from the bottom with one of 3,300 Collimonas mutants, while the top side was inoculated with $3 \mu \mathrm{l}$ of a $10^{5} \mathrm{ml}^{-1}$ spore suspension of $A$. niger. The plates were incubated at $20{ }^{\circ} \mathrm{C}$ for 5 days. The $\mathrm{pH}$-indicator in the agar facilitated the detection of non-inhibiting Collimonas mutants, as a color change from purple to yellow corresponded with the release of organic acids which typifies normal, i.e. uninhibited growth of $A$. niger. We used an inverse microscope (Leica DM IRB, Wetzlar, Germany) to confirm Collimonas-induced deformation of $A$. niger hyphae in yellow-colored wells. The loss of antifungal activity by mutants was validated by retesting the same mutants in a standard agar plate confrontation assay (as described above). The plasposon insertion sites of selected mutants were determined by genomic flank sequencing (Leveau et al., 2006), mapped onto the genome sequence of $C$. fungivorans Ter331 (NCBI accession number CP002745), and compared with published sequences using NCBI Blast (Altschul, 1990) and the Integrated Microbial Genomes site of the Joint Genome Institute (http://img.jgi.doe.gov). The organization of genes into putative operons was assessed using FgenesB (www.softberry.com). Southern blotting was used to 
307 confirm that each of the selected mutants harbored a single plasposon insertion (results not

308 shown).

309

310 Extraction of antifungal compound(s) from $C$. fungivorans Ter331 and activity profiling.

311 In a set of preliminary experiments, we discovered that extracts obtained from confrontation

312 plates with both $A$. niger and $C$. fungivorans Ter331 and from plates with strain Ter331 alone

313 (i.e. in the absence of the fungus) showed comparable levels of inhibition of hyphal growth.

314 Extracts from plates with the fungus alone did not inhibit hyphal growth (not shown). These

315 results indicated that the antifungal compound(s) were produced by Collimonas in the absence

316 of $A$. niger. Therefore, subsequent analyses were performed with extracts obtained from agar

317 plates with Collimonas only, thereby preventing the co-isolation of fungal metabolites.

318 For the extraction of antifungal compounds from $C$. fungivorans Ter331 and its plasposon

319 mutants, strains were grown on WYA containing $2 \mathrm{mM} \mathrm{N}$-acetylglucosamine. Agar pieces of

320 approximately $1 \mathrm{~cm}^{2}$ (surface area) were cut out, suspended in $80 \%$ acetone and shaken for $1 \mathrm{~h}$

321 at room temperature. After centrifugation at $4,800 \mathrm{rpm}$ for $15 \mathrm{~min}$, the liquid phase was

322 transferred and acetone was evaporated by nitrogen flow. The remaining aqueous phase was

323 acidified with trifluoroacetic acid (final concentration $0.1 \% \mathrm{v} / \mathrm{v}$ ) and extracted with 2 volumes

324 of ethyl acetate. After phase separation, the ethyl acetate was transferred to a new tube,

325 evaporated by nitrogen flow and the dried extract was dissolved in $100 \%$ HPLC-pure

326 methanol. To normalize the volumes between the different samples, we used $4 \mu \mathrm{l}$ of methanol

327 for every $10 \mathrm{~g}$ of agar material that entered the extraction protocol. Aliquots of the extracts

328 were immediately tested in confrontation assays with $\mathrm{A}$. niger or stored at $-20{ }^{\circ} \mathrm{C}$. The

329 inhibition assays were performed in 24-well plates containing in each well $1 \mathrm{ml}$ WYA

330 supplemented with $2 \mathrm{mM} N$-acetylglucosamine. A. niger was inoculated ( $5 \mu 1$ of a suspension

331 of $10^{6}$ spores per $\mathrm{ml}$ in $0.9 \% \mathrm{NaCl}$ ) in each well and away from the center of the well, grown 
$332 \mathrm{o} / \mathrm{n}$ at $30{ }^{\circ} \mathrm{C}$, at which point $5 \mu \mathrm{l}$ of an extract in methanol or methanol only (control) was

333 deposited on a Whatman filter paper disc (5 $\mathrm{mm}$ diameter) that was placed on the agar surface

334 opposite of the expanding A. niger colony. Plates were incubated at $30{ }^{\circ} \mathrm{C}$ and inhibition of

335 hyphal growth was scored after overnight incubation with an inverted microscope.

337 RP-HPLC analysis and fractionation. Agar plate extracts of cultures of wildtype strain 338 Ter331 and mutant 13E12 were analyzed by RP-HPLC (Waters Chromatography B.V., Etten-

339 Leur, The Netherlands) equipped with a Waters 996 photodiode array detector. The 340 separations were performed on a Waters Symmetry C18RP column $(5 \mu \mathrm{m}, 3.9 \times 150 \mathrm{~mm})$ with 341 a flow of $0.5 \mathrm{ml} / \mathrm{min}$. The solvent was water/acetonitrile containing $0.1 \%$ trifluoroacetic acid 342 (TFA). A linear gradient from 0 to $100 \%$ acetonitrile with $0.1 \%$ TFA was applied over 30 $343 \mathrm{~min}$, or $50 \mathrm{~min}$ for improved resolution of peaks. UV-detection took place at $240 \mathrm{~nm}$.

344 Fractions were collected and acetonitrile was evaporated under nitrogen flow. After addition 345 of $0.1 \%(\mathrm{v} / \mathrm{v})$ TFA to the aqueous phase, the fractions were extracted with 2 volumes of ethyl 346 acetate. The ethyl acetate phase was transferred to a new tube, evaporated under nitrogen flow 347 and the dried fractions were dissolved in $\mathrm{MeOH}$ and used in 24-well inhibition assays as 348 described above. The LC-UV-MS measurements were done on a Thermo Finnigan system:

349 Finnigan Surveyor Autosampler, MS Pump Plus HPLC, PDA Plus detector, and Finnigan

350 LXQ mass spectrometer with ESI-interface with positive ionization. Data were processed 351 with XCalibur software. Column and solvents were the same as described above.

353 PCR-based detection of cluster K genes. Four pairs of degenerated primers were designed 354 to amplify orthologs of Cf_1133, _1138, _1139, and _1141, based on alignment of these 355 genes from C. fungivorans Ter331 with those found on the genomes of Burkholderia 356 vietnamiensis G4, Burkholderia ambifaria Mex5, B. ambifaria IOP 40-10, P. protegens Pf-5 
357 and Streptomyces sp. Mg-1. Primer sequences were as follows: 1133A_f1,

358 GCICAYATGCCNTGGATG; 1133A_r1, AAIGCRTGRTGRTTRTTYTG; 1138B_f1,

359 TGGTAYCAYGGIYTNMGITAYGA; 1138B_r1, GCIACRTCYTTRTCYTCCAT;

360 1139B_f2, ATGACNCAYTGGAARCAYCA; 1139B_r1, CCRAARAANARIGCNGTRCA;

361 1141B_f1, GARYTIGTNTGGCARMG; 1141B_r1, ACCATIGCCATYTGDATRAA.

362 Bacterial DNA ( $1 \mu \mathrm{l}$ of $10 \mathrm{ng} / \mu \mathrm{l}$ ) was added to a $25 \mu \mathrm{l}$ (final volume) mixture containing 0.8

$363 \mu \mathrm{M}$ of each primer, $200 \mu \mathrm{M}$ dNTP's, $2.5 \mu \mathrm{l}$ of 10x buffer (Promega, Leiden, The

364 Netherlands), $2.5 \mathrm{mM} \mathrm{MgCl}_{2}$ and $0.04 \mathrm{U}$ Taq polymerase. Thermal cycling included the

365 initial denaturation step of $95^{\circ} \mathrm{C}$ for $3 \mathrm{~min}$, followed by a touchdown program in which the

366 annealing temperature decreased from $63{ }^{\circ} \mathrm{C}$ by $1{ }^{\circ} \mathrm{C}$ per cycle during the first 12 cycles,

367 followed by 13 cycli at $52{ }^{\circ} \mathrm{C}$ for $30 \mathrm{sec}$. The denaturing step was $30 \mathrm{sec}$ at $94{ }^{\circ} \mathrm{C}$ and the

368 elongation step was $50 \mathrm{sec}$ at $72{ }^{\circ} \mathrm{C}$. Cycling was completed by a final step of $5 \mathrm{~min}$ at $72^{\circ} \mathrm{C}$.

370 ACKNOWLEDGMENTS

371 The authors thank Arthur Ram for providing A. niger N402, Rob Samson for access to other

372 Aspergillus and Penicillium species, Saskia Gerards for maintenance of the C. fungivorans

373 Ter331 plasposon library, Menno van der Voort for analytical assays on the agar extracts and

374 Elbert van der Klift and Frank Claassen for their help with HPLC. This research was

375 supported in part by funds from the Netherlands Genomics Initiative/Ecogenomics cluster and

376 by startup funds to JHJL at UC Davis. This is NIOO-KNAW publication number XXXX. 


\section{REFERENCES}

378 Abraham, W.-R. (2010) Biosynthetic oils, fats, terpenes, sterols, waxes: analytical methods,

379 diversity, characteristics. In: Handbook of hydrocarbon and lipid microbiology, K. N.

380 Timmis (ed.), pages 79-95.

381 Ahlert, J., Shepard, E., Lomovskaya, N., Zazopoulos, E., Staffa, A., Bachmann, B.O., et al.

382 (2002) The calicheamicin gene cluster and its iterative type I enediyne PKS. Science 297:

$383 \quad 1173-1176$.

384 Altschul, S.F., Gish, W., Miller, W., Myers, E.W., and Lipman, D.J. (1990) Basic local

385 alignment search tool. J Mol Biol 215: 403-410.

386 Belecki, K., Crawford, J.M., and Townsend, C.A. (2009) Production of octaketide polyenes

387 by the calicheamicin polyketide synthase CalE8: implications for the biosynthesis of

388 enediyne core structures. J Amer Chem Soc 131: 12564-12566.

389 Bohlmann, F., Burkhardt, T., and Zdero, C. (1973) Naturally occurring acetylenes. Academic

390 Press, London.

391 Bos, C.J., Debets, A.J., Swart, K., Huybers, A., Kobus, G., and Slakhorst, S.M. (1988)

392 Genetic analysis and the construction of master strains for assignment of genes to six

393 linkage groups in Aspergillus niger. Curr Genet 14: 437-443.

394 De Boer, W., Leveau, J.H.J., Kowalchuk, G.A., Klein Gunnewiek, P.J.A., Abeln, E.C.A.,

395 Figge, M.J., et al. (2004) Collimonas fungivorans gen. nov., sp nov., a chitinolytic soil

396 bacterium with the ability to grow on living fungal hyphae. Int J Syst Evol Microbiol 54:

$397 \quad 857-864$.

398 Dembitsky, V.M. (2006) Anticancer activity of natural and synthetic acetylenic lipids. Lipids

399 41: 883-924.

400 Deng, S., Wang, Y., Inui, T., Chen, S.-N., Farnsworth, N.R., Cho, S., et al. (2008) Anti-TB

401 polyynes from the roots of Angelica sinensis. Phytoter Res 22: 878-882. 
402 Dennis, J.J., and Zylstra, G.J. (1998) Plasposons: modular self-cloning minitransposon

403 derivatives for rapid genetic analysis of gram-negative bacterial genomes. Appl Environ $404 \quad$ Microbiol 64: 2710-2715.

405 Fritsche, K., de Boer, W., Gerards, S., van den Berg, M., van Veen, J.A., and Leveau, J.H.J.

406 (2008) Identification and characterization of genes underlying chitinolysis in Collimonas

407 fungivorans Ter331. FEMS Microbiol Ecol 66: 123-135.

408 Hakvag, S., Fjaervik, E., Klinkenberg, G., Borgos, S.E.F., Josefsen, K.D., Ellingsen, T.E., and

409 Zotchev, S.B. (2009) Violacein-producing Collimonas sp. from the sea surface microlayer

410 of coastal waters in Trondelag, Norway. Marine Drugs 7: 576-588.

411 Haritos, V.S., Horne, I., Damcevski, K., Glover, K., Gibb, N., Okada, S., and Hamberg, M.

412 (2012) The convergent evolution of defensive polyacetylenic fatty acid biosynthesis genes

413 in soldier beetles. Nature Communications 3: 1150.

414 Hassan, K.A., Johnson, A., Shaffer, B.T., Ren, Q.H., Kidarsa, T.A., Elbourne, L.D.H., et al. 415 (2010) Inactivation of the GacA response regulator in Pseudomonas fluorescens Pf-5 has

416 far-reaching transcriptomic consequences. Environ Microbiol 12: 899-915.

417 Herrmann, K.M. (1999) The shikimate pathway. Annu Rev Plant Physiol Plant Mol Biol 50: $418 \quad 473-503$.

419 Holden, H.M., Thoden, J.B., and Raushel, F.M. (1999): Carbamoyl phosphate synthetase: an 420 amazing biochemical odyssey from substrate to product. Cell Mol Life Sci 56: 507-522.

421 Höppener-Ogawa, S., de Boer, W., Leveau, J.H.J., van Veen, J.A., de Brandt, E., Vanlaere, 422 E., et al. (2008) Collimonas arenae sp nov and Collimonas pratensis sp nov., isolated from 423 (semi-)natural grassland soils. Int J Syst Evol Microbiol 58: 414-419.

424 Kusumi, T., Ohtani, I., Nishiyama, K., and Kakisawa, H. (1987) Caryoynencins, potent 425 antibiotics from a plant pathogen Pseudomonas caryophylli. Tetrahedron Lett 28: 39814263984. 
427 Lee, E.H., and Shafer, W.M. (1999) The farAB-encoded efflux pump mediates resistance of 428 gonococci to long-chained antibacterial fatty acids. Mol Microbiol 33: 839-845.

429 Leveau, J.H.J., Gerards, S., Fritsche, K., Zondag, G., and van Veen, J.A. (2006) Genomic

430 flank-sequencing of plasposon insertion sites for rapid identification of functional genes. $J$ 431 Microbiol Methods 66: 276-285.

432 Leveau, J.H.J., and Preston, G.M. (2008) Bacterial mycophagy: definition and diagnosis of a 433 unique bacterial-fungal interaction. New Phytologist 177: 859-876.

434 Leveau, J.H.J., Uroz, S., and de Boer, W. (2010) The bacterial genus Collimonas:

435 mycophagy, weathering and other adaptive solutions to life in oligotrophic soil 436 environments. Environ Microbiol 12: 281-292.

437 Lin, X., and Momany, M. (2004) Identification and complementation of abnormal hyphal 438 branch mutants ahbA1 and ahbB1 in Aspergillus nidulans. Fungal Genet Biol 41: 998-1006. 439 Loper, J.E., and Gross, H. (2007) Genomic analysis of antifungal metabolite production by $440 \quad$ Pseudomonas fluorescens Pf-5. Eur J Plant Pathol 119: 265-278.

441 Loper, J.E., Hassan, K.A., Mavrodi, D.V., Davis II, E.W., Lim, C.K., Shaffer, B.T., et al. 442 (2012) Comparative genomics of plant-associated Pseudomonas spp: insights into diversity 443 and inheritance of traits involved in multitrophic interactions. PLoS Genet 8:e1002784 444 Matz, C., Deines, P., Boenigk, J., Arndt, H., Eberl, L., Kjelleberg, S., and Jürgens, K. (2004) 445 Impact of violacein-producing bacteria on survival and feeding of bacterivorous 446 nanoflagellates. Appl Environ Microbiol 70: 1593-1599.

447 Mela, F., Fritsche, K., de Boer, W., van Veen, J.A., de Graaff, L.H., van den Berg, M., and 448 Leveau, J.H.J. (2011) Dual transcriptional profiling of a bacterial/fungal confrontation: 449 Collimonas fungivorans versus Aspergillus niger. ISME J 5: 1494-1504. 450 Mela, F., Fritsche, K., de Boer, W., van den Berg, M., van Veen, J.A., Maharaj, N.N., and 451 Leveau, J.H.J. (2012) Comparative genomics of bacteria from the genus Collimonas: 
452 linking (dis)similarities in gene content to phenotypic variation and conservation. Environ $453 \quad$ Microbiol Reports 4: 424-432.

454 Minto, R.E., and Blacklock, B.J. (2008) Biosynthesis and function of polyacetylenes and 455 allied natural products. Prog Lipid Res 47: 233-306.

456 Myers, A.G., Cohen, S.B, and Kwon, B.M. (1994) A study of the reaction of calicheamicin 457 Y1 with glutathione in the presence of double-stranded DNA. J Am Chem Soc 116:1255$458 \quad 12911255$.

459 Onishi, J.C., Abruzzo, G.K., Fromtling, R.A., Garrity, G.M., Milligan, J.A., Pelak, B.A., and 460 Rozdilsky, W. (2006) Mode of action of L-660,631 in Candida albicans. Ann New York $461 \quad$ Acad Sci 544: 229.

462 Parish, C.A., Huber, J., Baxter, J., Gonzalez, A., Collado, J., Platas, G., et al. (2004) A new 463 ene-triyne antibiotic from the fungus Baeospora myosura. J Natural Products 67: 1900$464 \quad 1902$.

465 Parker, W.L., Rathnum, M.L., Seiner, V., Trejo, W.H., Principe, P.A., and Sykes, R.B. (1984)

466 Cepacin-A and cepacin-B, 2 new antibiotics produced by Pseudomonas cepacia. J $467 \quad$ Antibiotics 37: 431-440.

468 Paulsen, I.T., Press, C.M., Ravel, J., Kobayashi, D.Y., Myers, G.S.A., Mavrodi, D.V., et al. 469 (2005) Complete genome sequence of the plant commensal Pseudomonas fluorescens Pf-5. $470 \quad$ Nature Biotechnology 23: 873-878.

471 Shi Shun, A.L.K., and Tykwinski, R.R. (2006) Synthesis of naturally occurring polyynes. $472 \quad$ Angew Chem Int Ed 45: 1034-1057.

473 Van den Brink, H.J.M., Van Gorcom, R.F.M., Van den Hondel, C., and Punt, P.J. (1998)

474 Cytochrome P450 enzyme systems in fungi. Fungal Genet Biol 23: 1-17.

475 Yamaguchi, M., Park, H.J., Ishizuka, S., Omata, K., and Hirama, M. (1995) Chemistry and 476 antimicrobial activity of caryoynencins analogs. J Med Chem 38: 5015-5022. 


\begin{tabular}{|c|c|c|c|c|c|c|c|}
\hline Collimonas species and subgroup & $\begin{array}{l}\text { strain } \\
\text { number }\end{array}$ & LMG & $\begin{array}{c}\text { Inhibition of } \\
\text { A. niger }\end{array}$ & $\begin{array}{c}\text { PCR } \\
1133^{*}\end{array}$ & $\begin{array}{c}\text { PCR } \\
1138^{*}\end{array}$ & $\begin{array}{c}\text { PCR } \\
\text { 1139* }\end{array}$ & $\begin{array}{l}\text { PCR } \\
\text { 1141* }\end{array}$ \\
\hline \multirow[t]{14}{*}{ C. fungivorans subgroup B } & Ter 331 & & + & + & + & + & + \\
\hline & Ter 165 & & + & + & + & + & + \\
\hline & Ter 228 & 23972 & + & + & + & + & + \\
\hline & Ter 266 & 23971 & + & + & + & + & + \\
\hline & Ter 299 & & + & + & + & + & + \\
\hline & Ter 14 & & + & + & + & + & + \\
\hline & SO 6 & & + & + & + & + & + \\
\hline & SO 7 & & + & + & + & + & + \\
\hline & SO 8 & & + & + & + & + & + \\
\hline & SO 9 & & + & + & + & + & + \\
\hline & SO 30 & & - & - & n.t. & n.t. & n.t. \\
\hline & SO 114 & & + & + & + & + & + \\
\hline & SO 115 & & - & + & - & - & - \\
\hline & SO 147 & 23973 & + & + & + & + & + \\
\hline \multirow[t]{4}{*}{ C. fungivorans subgroup $\mathrm{C}$} & Ter $6^{\mathrm{T}}$ & 21973 & - & + & - & - & - \\
\hline & Ter 166 & & - & + & - & - & - \\
\hline & Ter 330 & 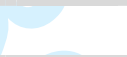 & - & + & - & - & - \\
\hline & Ter 300 & & - & + & - & - & - \\
\hline \multirow[t]{4}{*}{ C. arenae } & Ter $10^{\mathrm{T}}$ & 23964 & - & - & - & - & - \\
\hline & Ter 146 & & - & - & - & - & - \\
\hline & Ter 252 & & - & - & - & - & - \\
\hline & Ter 282 & 23966 & - & - & $+/-$ & - & - \\
\hline \multirow[t]{15}{*}{ C. pratensis } & Ter $91^{\mathrm{T}}$ & 23965 & - & - & - & - & - \\
\hline & Ter 227 & & - & - & - & - & - \\
\hline & Ter 90 & & - & - & - & - & - \\
\hline & Ter 118 & & - & - & - & - & - \\
\hline & Ter 113 & & - & - & - & - & - \\
\hline & Ter 291 & 23970 & - & - & - & - & - \\
\hline & SO 31 & & - & - & n.t. & n.t. & n.t. \\
\hline & SO 32 & & - & - & n.t. & n.t. & n.t. \\
\hline & SO 85 & & - & - & n.t. & n.t. & n.t. \\
\hline & SO 108 & & - & - & n.t. & n.t. & n.t. \\
\hline & SO 110 & & - & - & n.t. & n.t. & n.t. \\
\hline & SO 111 & 23968 & - & - & n.t. & n.t. & n.t. \\
\hline & SO 113 & & - & - & n.t. & n.t. & n.t. \\
\hline & SO 117 & & - & - & n.t. & n.t. & n.t. \\
\hline & SO 195 & & - & - & n.t. & n.t. & n.t. \\
\hline Pseudomonas protegens & Pf-5 & & - & + & - & - & - \\
\hline
\end{tabular}




\begin{tabular}{|c|c|c|c|c|c|c|}
\hline $\begin{array}{l}\text { Gene Cf_xxxx } \\
\text { (CFU_Xxxx) }\end{array}$ & $\begin{array}{l}\text { Length/Mw } \\
\text { aa/kDa }\end{array}$ & Features $^{1}$ & $\begin{array}{c}\text { Most similar protein, Organism, } \\
\text { Accession Number (gene ID genome } \\
\text { sequence) }\end{array}$ & $\begin{array}{l}\text { Length of } \\
\text { alignment in } \\
\text { aa } \\
\text { \%identity/ } \\
\text { \%similarity }\end{array}$ & $\begin{array}{l}\text { Best experimental hit } \\
\quad \text { (organism) } \\
\text { Accession No., reference }^{2}\end{array}$ & $\begin{array}{l}\text { Length of } \\
\text { alignment in } \\
\text { aa } \\
\text { \%identity/ } \\
\text { \%similarity }\end{array}$ \\
\hline $1127(1076)$ & $265 / 27.9$ & & $\begin{array}{l}\text { hypothetical protein } \\
\text { Predicted hydrolases or acyltransferases } \\
\text { Sorangium cellulosum 'So ce 56' } \\
\text { CAN93372, Schneiker et al., } 2007\end{array}$ & $\begin{array}{l}241 \\
38 / 53\end{array}$ & $\begin{array}{l}\text { lactone-specific esterase } \\
\text { Pseudomonas fluorescens } \\
\text { AAC36352, Hildebrandt et al., } 2002\end{array}$ & $\begin{array}{l}143 \\
30 / 49\end{array}$ \\
\hline 1128 & $39 / 4.2$ & & Hypothetical, no hit & & - & \\
\hline $1129(1078)$ & $61 / 6.9$ & & $\begin{array}{l}\text { Rubredoxin-type } \mathrm{Fe}(\mathrm{Cys}) 4 \text { protein } \\
\text { Burkholderia vietnamiensis } \mathrm{G} 4 \\
\text { ABO56995 } \\
\text { (GENE ID: } 4950229 \text { Bcep1808 4014) }\end{array}$ & $\begin{array}{l}61 \\
67 / 77\end{array}$ & $\begin{array}{l}\text { Rubredoxin } \\
\text { Acinetobacter sp. M-1 } \\
\text { BAB33291; Tani } \text { et al., } 2001\end{array}$ & $\begin{array}{l}52 \\
65 / 78\end{array}$ \\
\hline $1130(1079)$ & $317 / 33.5$ & & $\begin{array}{l}\text { Predicted hydrolase } \\
\text { Burkholderia ambifaria IOP40- } \\
\text { 10EDT06087 }\end{array}$ & $\begin{array}{l}287 \\
49 / 65\end{array}$ & $\begin{array}{l}\text { FMP } \\
\text { Ralstonia eutropha } \mathrm{H} 16 \\
\text { AAA21950; Priefert et al., } 1991\end{array}$ & $\begin{array}{l}192 \\
27 / 42\end{array}$ \\
\hline $1131(1080)$ & $366 / 42.1$ & $5 \mathrm{TMH}$ & $\begin{array}{l}\text { fatty acid desaturase } \\
\text { Burkholderia ambifaria } \text { MEX-5 } \\
\text { EDT43257 }\end{array}$ & $\begin{array}{l}362 \\
68 / 82\end{array}$ & $\begin{array}{l}\text { delta-12 desaturase } \\
\text { Synechococcus sp. PCC } 6714 \\
\text { BAA02921; Sakamoto et al., } 1994\end{array}$ & $\begin{array}{l}321 \\
34 / 54\end{array}$ \\
\hline $1132(1081)$ & $110 / 12.1$ & & $\begin{array}{l}\text { phosphopantetheine-binding } \\
\text { Burkholderia ambifaria IOP40-10 } \\
\text { EDT06085 }\end{array}$ & $\begin{array}{l}109 \\
68 / 80\end{array}$ & $\begin{array}{l}\text { polyketide synthase (phosphopante- } \\
\text { theine attachment site } \\
\text { Chondromyces crocatus } \\
\text { CAJ46689: Rachid et al., } 2006 \\
\end{array}$ & $\begin{array}{l}72 \\
40 / 65\end{array}$ \\
\hline $1133(1082)$ & $322 / 35.1$ & $5 \mathrm{TMH}$ & $\begin{array}{l}\text { delta-9 acyl-phospholipid desaturase } \\
\text { Burkholderia ambifaria IOP40-10 } \\
\text { EDT06084 }\end{array}$ & $\begin{array}{l}298 \\
78 / 86\end{array}$ & $\begin{array}{l}\text { fatty acid desaturase JamB } \\
\text { Lyngbya majuscule } \\
\text { AAS98775; Edwards et al., } 2004\end{array}$ & $\begin{array}{l}283 \\
40 / 58\end{array}$ \\
\hline $1134(1083)$ & $315 / 34.6$ & $4 \mathrm{TMH}$ & $\begin{array}{l}\text { Stearoyl-CoA 9-desaturase } \\
\text { Burkholderia ambifaria MEX-5 } \\
\text { EDT43254 }\end{array}$ & $\begin{array}{l}304 \\
58 / 70\end{array}$ & $\begin{array}{l}\text { fatty acid desaturase JamB } \\
\text { Lyngbya majuscula } \\
\text { AAS98775; Edwards et al., } 2004\end{array}$ & $\begin{array}{l}305 \\
36 / 55\end{array}$ \\
\hline $1135(1084)$ & $617 / 65.8$ & & $\begin{array}{l}\text { AMP-dependent synthetase and ligase } \\
\text { ABO56989 } \\
\text { (GENE ID: } 4950224 \text { Bcep1808 4008) }\end{array}$ & $\begin{array}{l}582 \\
54 / 67\end{array}$ & $\begin{array}{l}\text { nonribosomal peptide synthetase } \\
\text { Streptomyces atroolivaceus } \\
\text { AAN85512; Cheng et al., } 2003\end{array}$ & $\begin{array}{l}570 \\
40 / 54\end{array}$ \\
\hline $1136(1085)$ & $472 / 49.2$ & $14 \mathrm{TMH}$ & $\begin{array}{l}\text { major facilitator superfamily MFS_1 } \\
\text { Burkholderia ambifaria MEX-5 } \\
\text { EDT43252 }\end{array}$ & $\begin{array}{l}472 \\
85 / 90\end{array}$ & $\begin{array}{l}\text { ChaT1 protein } \\
\text { Streptomyces chartreusis } \\
\text { CAH10178; Xu et al., } 2005\end{array}$ & $\begin{array}{l}411 \\
31 / 47\end{array}$ \\
\hline 1137 & $281 / 30.6$ & & $\begin{array}{l}\text { hypothetical protein } \\
\text { Burkholderia ambifaria IOP40-10 }\end{array}$ & $\begin{array}{l}277 \\
80 / 87 \\
\end{array}$ & - & \\
\hline
\end{tabular}




\begin{tabular}{|c|c|c|c|c|c|c|}
\hline & & & EDT06080 & & & \\
\hline $1138(1086)$ & $344 / 38.9$ & & $\begin{array}{l}\text { Rieske (2Fe-2S) domain protein } \\
\text { Burkholderia ambifaria IOP40-10 } \\
\text { EDT06079 }\end{array}$ & $\begin{array}{l}333 \\
88 / 95\end{array}$ & $\begin{array}{l}\text { alpha-subunit oxygenase VanA } \\
\text { Streptomyces sp. NL15-2K } \\
\text { BAF33363; Nishimura et al., } 2006\end{array}$ & $\begin{array}{l}338 \\
34 / 49\end{array}$ \\
\hline $1139(1087)$ & $360 / 40.5$ & $5 \mathrm{TMH}$ & $\begin{array}{l}\text { fatty acid desaturase } \\
\text { Burkholderia ambifaria IOP40-10 } \\
\text { EDT06078 }\end{array}$ & $\begin{array}{l}360 \\
75 / 85\end{array}$ & $\begin{array}{l}\text { carotene ketolase CrtW } \\
\text { Algoriphagus sp. KK10202C } \\
\text { ABB88952; Tao et al., 2006 }\end{array}$ & $\begin{array}{l}261 \\
22 / 38\end{array}$ \\
\hline $1140(1088)$ & $461 / 50.5$ & s. & $\begin{array}{l}\text { monooxygenase, FAD-binding } \\
\text { Burkholderia ambifaria } \text { MEX-5 } \\
\text { EDT43248 }\end{array}$ & $\begin{array}{l}461 \\
80 / 88\end{array}$ & $\begin{array}{l}\text { Halogenase, Actinosynnema pretiosum } \\
\text { subsp. auranticum } \\
\text { AAM54090; Yu et al., } 2002\end{array}$ & $\begin{array}{l}347 \\
29 / 40\end{array}$ \\
\hline $1141(1089)$ & $430 / 44.4$ & & $\begin{array}{l}\text { 3-oxoacyl-acyl carrier protein synthase II } \\
\text { Burkholderia ambifaria MEX-5 } \\
\text { EDT43247 }\end{array}$ & $\begin{array}{l}421 \\
84 / 92\end{array}$ & $\begin{array}{l}\text { Pseudomonas syringae pv. phaseolicola } \\
\text { CAI36078; Pitman et al., } 2005\end{array}$ & $\begin{array}{l}421 \\
63 / 78\end{array}$ \\
\hline 1142 & $57 / 6.4$ & $1 \mathrm{TMH}$ & $\begin{array}{l}\text { similar to CG3523-PA } \\
\text { Tribolium castaneum XP_974066 }\end{array}$ & $\begin{array}{l}39 \\
43 / 61\end{array}$ & - & \\
\hline 1143 & $326 / 36.4$ & $1 \mathrm{HTH}$ & $\begin{array}{l}\text { transcriptional regulator, LysR family } \\
\text { Burkholderia vietnamiensis G4 } \\
\text { ABO54218 } \\
\text { (GENE ID: } 4952917 \text { Bcep1808_1207) }\end{array}$ & $\begin{array}{l}309 \\
56 / 76\end{array}$ & $\begin{array}{l}\text { Chain A, Crystal Structure Of The } \\
\text { Effector Binding Domain Of A Catm } \\
\text { Variant, Catm(V158m), } \\
\text { Acinetobacter sp. 2H98_A, } \\
\text { Ezezika et al., 2007 }\end{array}$ & $\begin{array}{l}298 \\
24 / 47\end{array}$ \\
\hline $1144(1091)$ & $440 / 47.4$ & $11 \mathrm{TMH}$ & $\begin{array}{l}\text { major facilitator family transporter } \\
\text { Burkholderia pseudomallei } 668 \\
\text { ZP 01764941 }\end{array}$ & $\begin{array}{l}413 \\
72 / 83\end{array}$ & $\begin{array}{l}\text { MopB } \\
\text { Burkholderia cepacia } \\
\text { AAB41509; Saint and Romas, } 1996\end{array}$ & $\begin{array}{l}423 \\
37 / 56\end{array}$ \\
\hline $1145(1092)$ & $457 / 48.1$ & $\begin{array}{l}\mathrm{SP} \\
12 \mathrm{TMH}\end{array}$ & $\begin{array}{l}\text { conserved hypothetical protein } \\
\text { Burkholderia phymatum STM815 } \\
\text { ACC76384 }\end{array}$ & $\begin{array}{l}406 \\
48 / 66\end{array}$ & - & \\
\hline $1145 \mathrm{a}$ & $310 / 35.7$ & $4 \mathrm{TMH}$ & $\begin{array}{l}\text { fatty acid desaturase Burkholderia } \\
\text { phymatum STM } 815 \\
\text { ACC76383 }\end{array}$ & $\begin{array}{l}307 \\
44 / 62\end{array}$ & $\begin{array}{l}\text { RtxC } \\
\text { Bradyrhizobium elkanii } \\
\text { BAB55901; Okazaki et al., } 2004\end{array}$ & $\begin{array}{l}310 \\
24 / 43\end{array}$ \\
\hline$(1093)$ & 26 & & transposase, Burkholderia thailandensis & $\begin{array}{ll}26 \\
81 / 88\end{array}$ & $\sqrt{P}$ & \\
\hline$(1094)$ & 42 & & transposase, Burkholderia glumae & $\begin{array}{l}42 \\
62 / 73\end{array}$ & 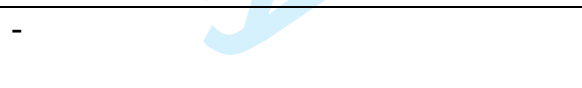 & \\
\hline
\end{tabular}

${ }^{1}$ TMH, transmembrane helix; HTH, helix turn helix motif; SP, signal peptide

${ }^{2}$ Schneiker et al., 2007 Nature Biotech 25: 1281-1289; Hildebrandt et al., 2002 Appl Microbiol Biotechnol 59: 483-487; Tani et al., 2001 J Bacteriol 183: $1819-1823$; Priefert et al., 1991 J. Bacteriol. 173: 4056-4071; Sakamoto et al., 1994 Plant Mol Biol 24: 643-650; Rachid et al., 2006 Chem Biol 13: 667-681; Edwards et al., 2004 Chem Biol 11: 817-833; Cheng et al., 2003 Proc Natl Acad Sci USA 100: 3149-3154; Xu et al., 2005 Chem Biol 12: 579-588; Nishimura et al., 2006 Biosci Biotechnol Biochem 70: 2316-2319; Tao et al., 2006 Mol Genet Genomics 486 276: 79-86; Yu et al., 2002 Proc Natl Acad Sci USA 99: 7968-7973; Pitman et al., 2005 Curr Biol 15: 2230-2235; Saint and Romas, 1996 Microbiology 142: 2407-2418; Okazaki et al., 4872004 Appl Environ Microbiol 70: 535-541. 
490 Figure 1. Macroscopic (top) or microscopic (bottom) view of hyphal growth of $A$. niger in the 491 absence (left) or presence (right) of C. fungivorans Ter331 on WYA-Nag agar. Scale bars in the 492 bottom photographs represent approximately 20 micrometers.

494 Figure 2. A) Graphical representation of cluster K and surrounding genes on the C. fungivorans

495 Ter331 genome. Genes are labeled according to the naming convention established in Mela et al.

496 (2011) and Mela et al. (2012). For example, the gene labeled 1135 corresponds with gene

497 Cf_1135 in these papers. Genes for which the label is underlined are part of gene cluster K:

498 genes in this cluster were upregulated during confrontation of $C$. fungivorans Ter331 with $A$.

499 niger (Mela et al., 2011). Gene colors indicate predicted function (also see Table S1). Arrowed

500 lines above the genes indicate operonic organization, as predicted by FgenesB

501 (www.softberry.com). Black arrow heads indicate the plasposon insertion sites in mutants

502 13E12, 8G9, and 28A12. B) Also shown are orthologous regions from the genomes of

503 Burkholderia vietnamiensis G4 (gene accession numbers Bcep1808_...), Burkholderia sp. KJ006

504 (MYA_...), Burkholderia ambifaria IOP40-10 (BamIOP4010DRAFT_...) and MEX5

505 (BamMEX5DRAFT_...), Burkholderia gladioli BSR3 (bgla_1g20...), Streptomyces sp. Mg1

506 (SSAG_033..), and Pseudomonas protegens Pf-5 (PFL_026..) and CHA0 (PFLCHA0_c02...).

508 Figure 3. Antifungal activity screening of extracts from $C$. fungivorans Ter331, its rifampicin509 resistant derivative Ter331R3, and mutants 8G9, 13E12, and 28A12. Details are described in the 510 section Experimental Procedures, under the heading 'Extraction of antifungal compound(s) from 511 C. fungivorans Ter331 and activity profiling'. In short, each well contained $1 \mathrm{ml}$ of WYA-Nag 
512 agar, on which was deposited $5 \mu$ of extract on a filter paper disc (right) opposite of a spore

513 suspension of $A$. niger (left). Inhibition of fungal outgrowth was observed only with Ter331 and

514 Ter331R, not with any one of the mutants or with the methanol $(\mathrm{MeOH})$ control.

516 Figure 4. A) Aligned HPLC profiles of methanol extracts from C. fungivorans Ter331 and 517 mutant 13E12. Gradient used was $0-100 \%$ acetonitrile over a period of 30 minutes. Peak labels 518 are a through h, and correspond to peak labels in Figure 5. B) Antifungal activity screening of 519 seven 5-min fractions collected for both C. fungivorans Ter331 (top row) and mutant $13 \mathrm{E} 12$

520 (bottom row) extracts. Assay was done in the same way as shown in Figure 3. Antifungal activity 521 was observed only in the two fractions that are boxed by the black rectangle. C) Blowup of the 522 two wildtype wells that are shown boxed in panel B, as well as of the two corresponding wells 523 for mutant 13E12 extract showing loss of activity.

525 Figure 5. A) Improved-resolution HPLC profile of methanol extract from C. fungivorans

526 Ter331. Gradient used was $0-100 \%$ acetonitrile over a period of 50 minutes. Five fractions were 527 collected (shaded areas), and asterisks mark those fractions that retained antifungal activity 528 against $A$. niger. Peak labels are a through h, and correspond to peak labels in Figure 4. B) UV 529 spectra of peaks in fractions collected from HPLC profile in panel A. The UV spectra of peaks d 530 (32.04) and g (36.27) are not shown; they were very similar to those of $\mathrm{c}$ and $\mathrm{f}$, respectively.

532 Figure S1. Hyphal growth of Aspergillus niger, A. versicolor, A. westerdijkiae, Penicillium 533 chrysogenum, and P. glabrum in the absence and presence of C. fungivorans Ter331 or mutants $534 \quad 13 \mathrm{E} 12$ and $8 \mathrm{G} 9$. 
536 Figure S2. HPLC trace for extract from mutant 28A12 (top), compared to those of Ter331 wt

537 (middle) and mutant 13E12 (bottom). HPLC conditions were different from those shown in

538 Figures 4 and 5: Dionex HPLC with photodiode array detector; detection at 240nm; 4.6mm,

539 5um, 250mm C18RP column (Grace/Alltech, Breda, NL); flow: 1ml/min; solvent:

540 acetonitrile/water with $0.1 \%$ (v/v) TFA; gradient: 5 min 30 to $35 \%$ acetonitrile, 5 min $35 \%, 15$

$541 \min 35$ to $41 \%, 1 \min 41$ to $43 \%, 25 \min 43$ to $45 \%, 6 \min 45$ to $49 \%, 7 \min 49$ to $100 \%, 10 \min$ $542 \quad 100 \%$. 
Figure 1
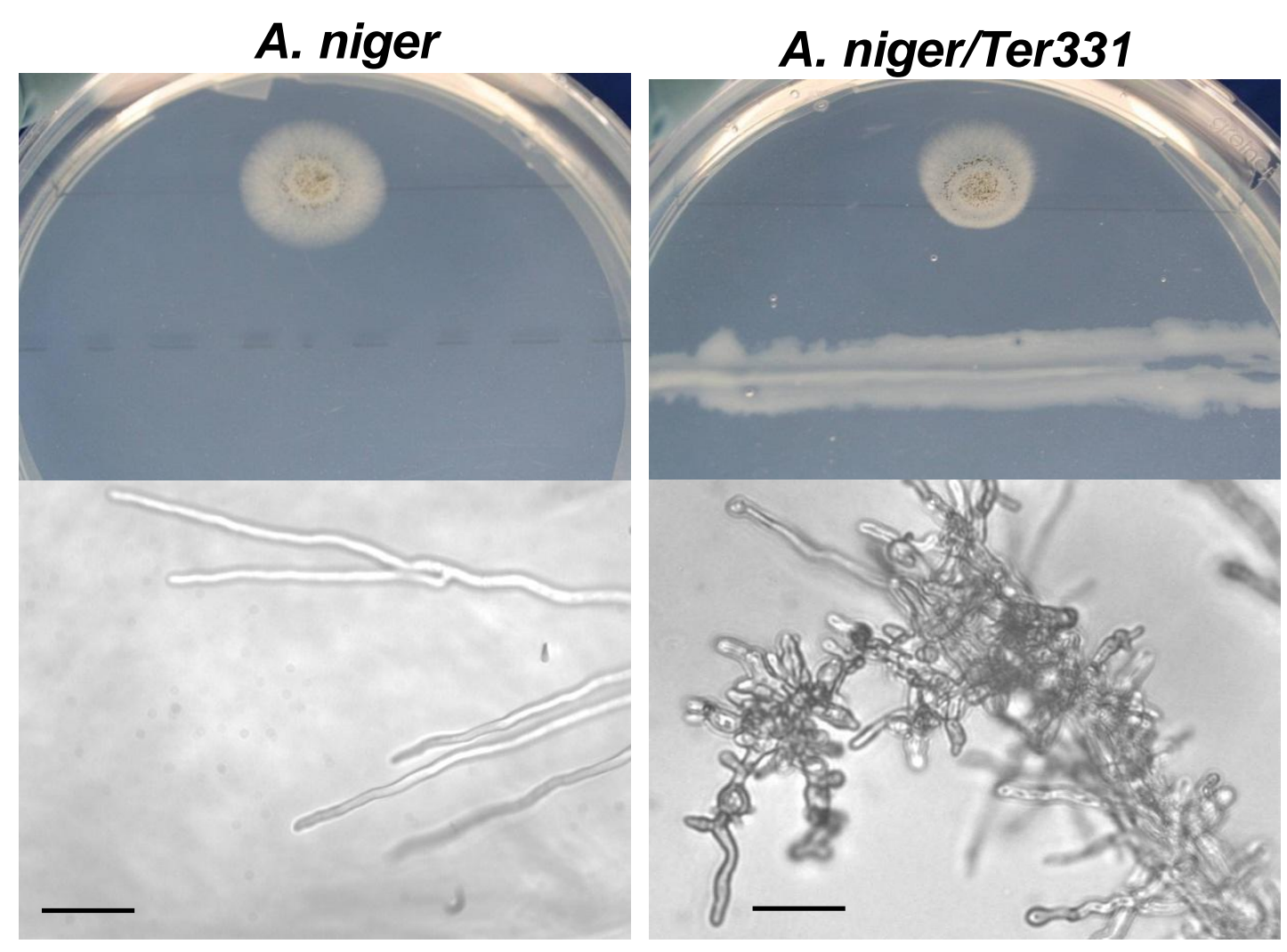


\section{Figure 2}
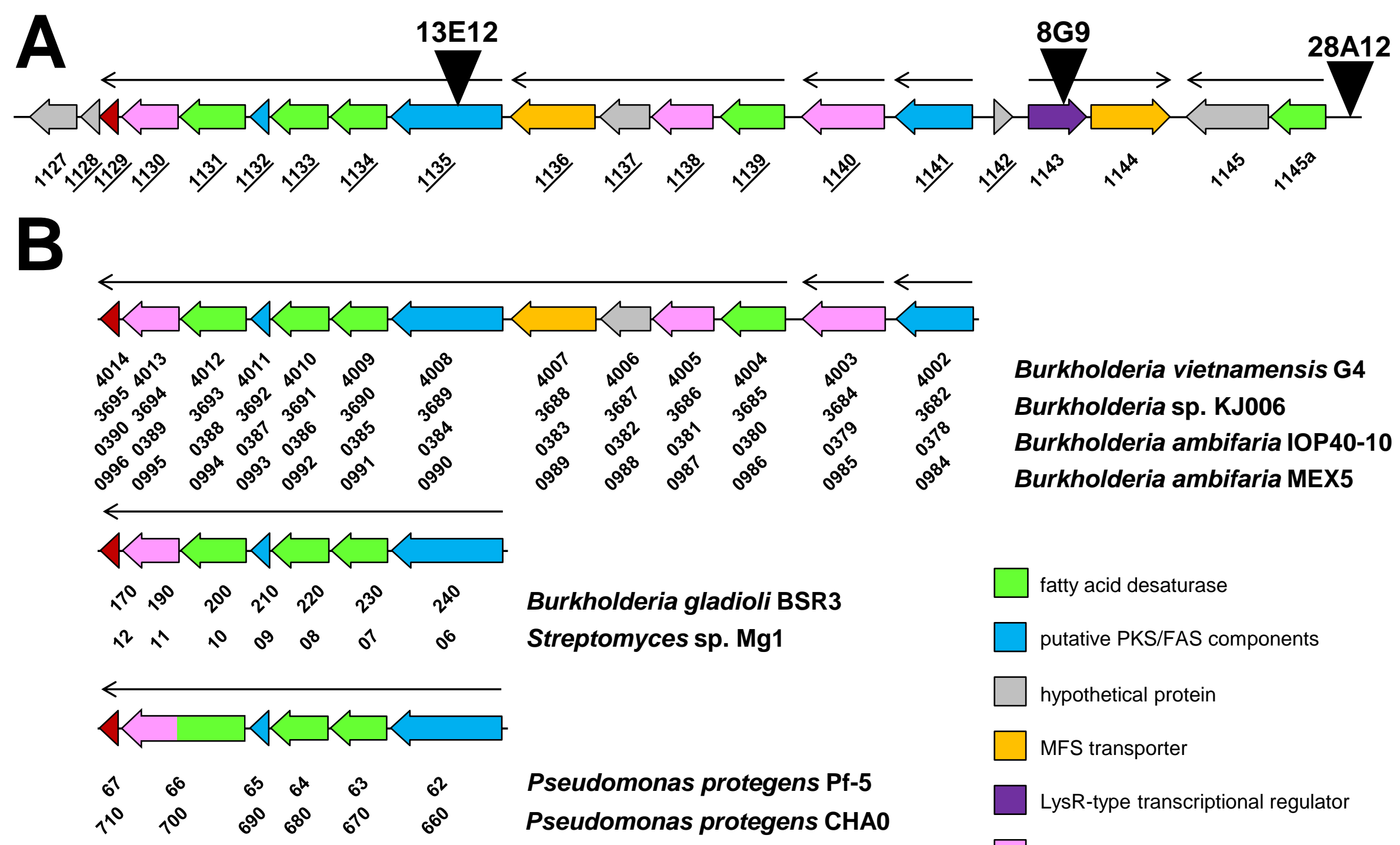

Burkholderia vietnamensis G4

Burkholderia sp. KJ006

Burkholderia ambifaria IOP40-10

Burkholderia ambifaria MEX5

fatty acid desaturase

putative PKS/FAS components

hypothetical protein

MFS transporter

LysR-type transcriptional regulator

hydrolase, monooxygenase, or oxygenase

Wiley-Blackwell and Society for Appiried Microblology

rubredoxin-type protein 
Figure 3

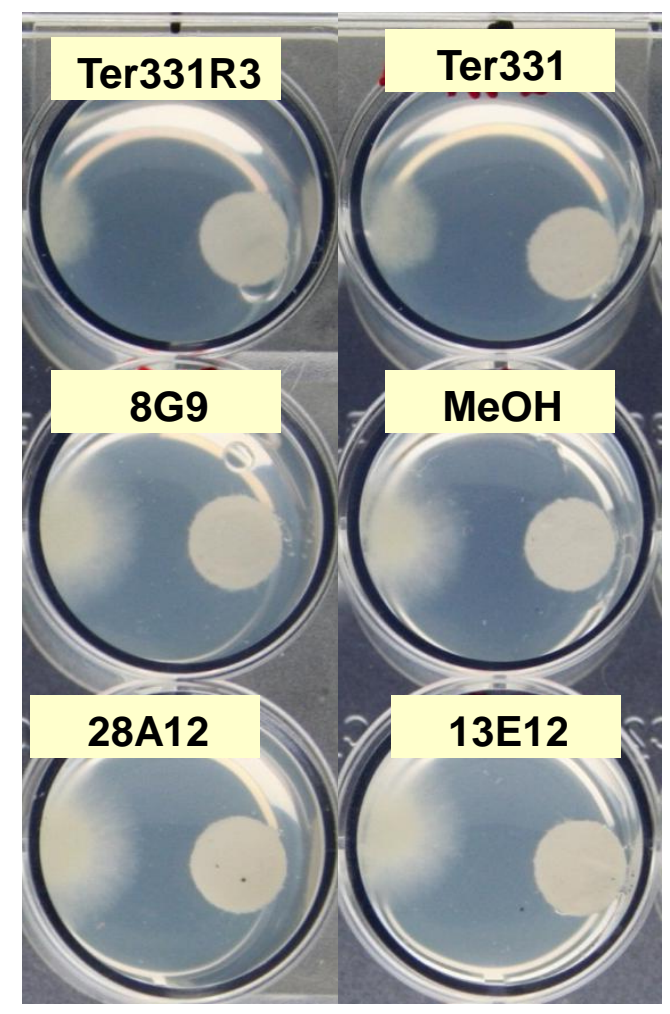


Figure 4

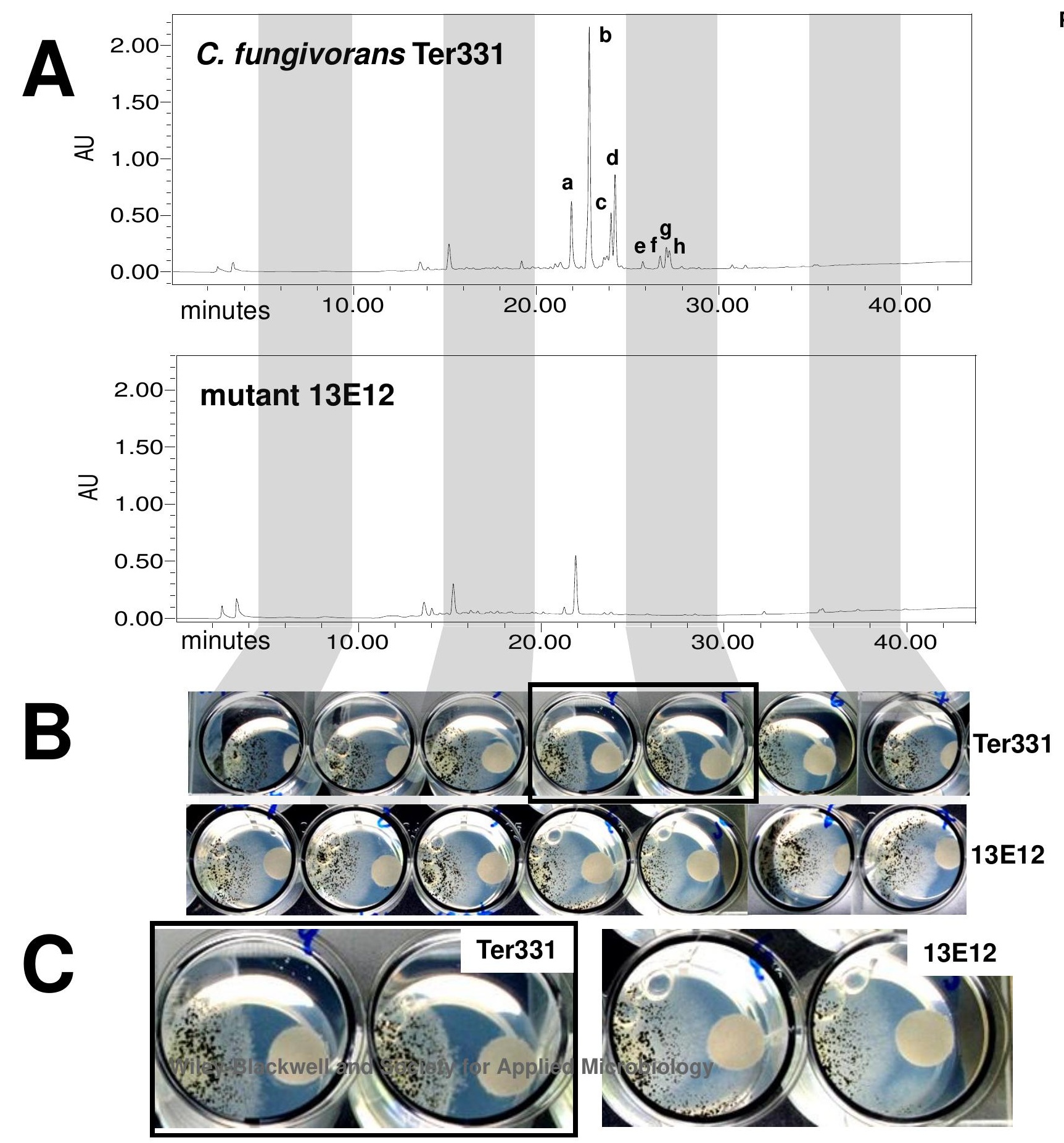

Page 30 of 33 


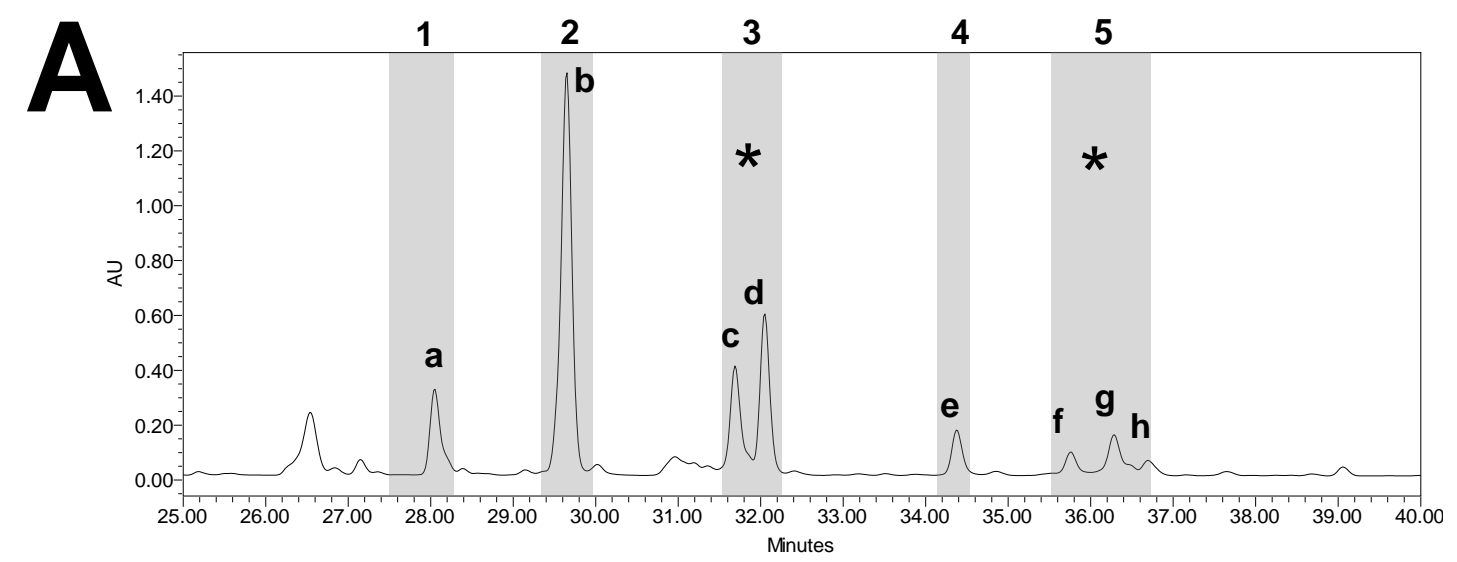

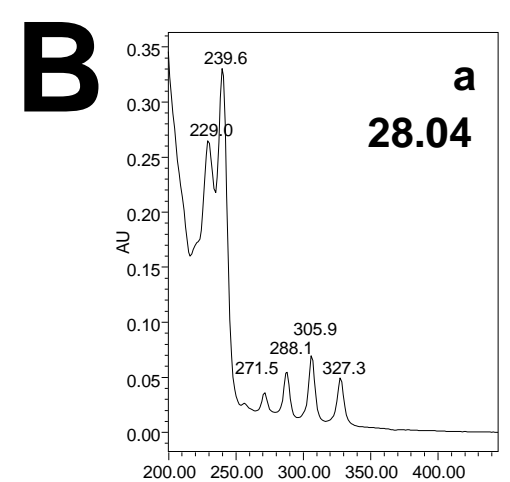

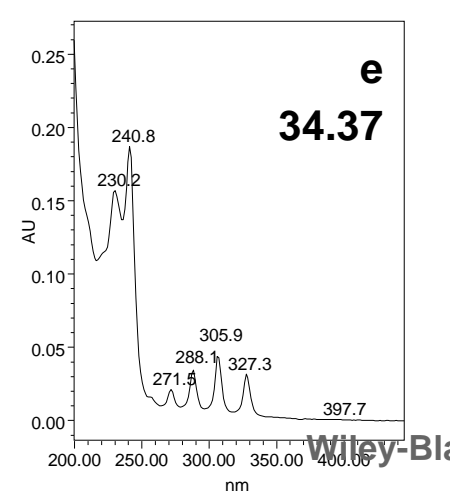

$\mathrm{nm}$

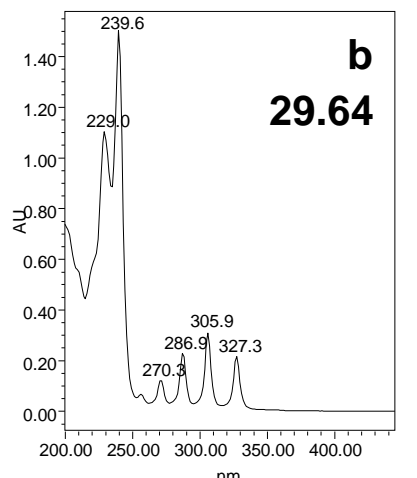

$\mathrm{nm}$

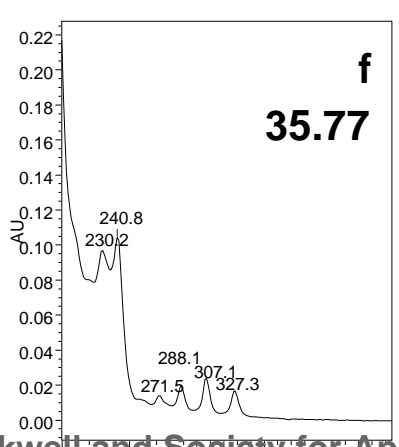

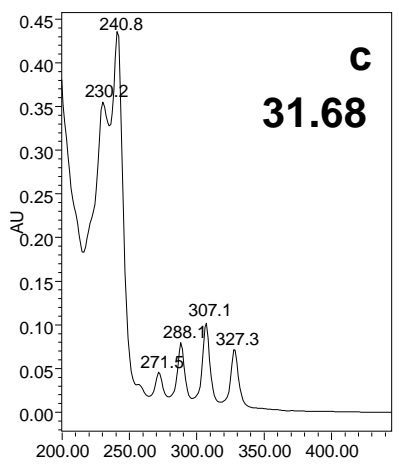

$\mathrm{nm}$

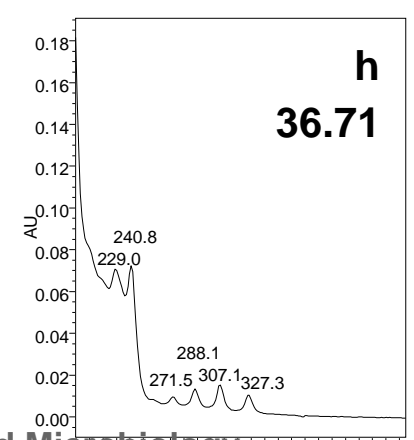

0.00

$\sim^{271.5} \underbrace{307.3}$

68d.d\% 350.00400 .00 
Figure S1

A. niger
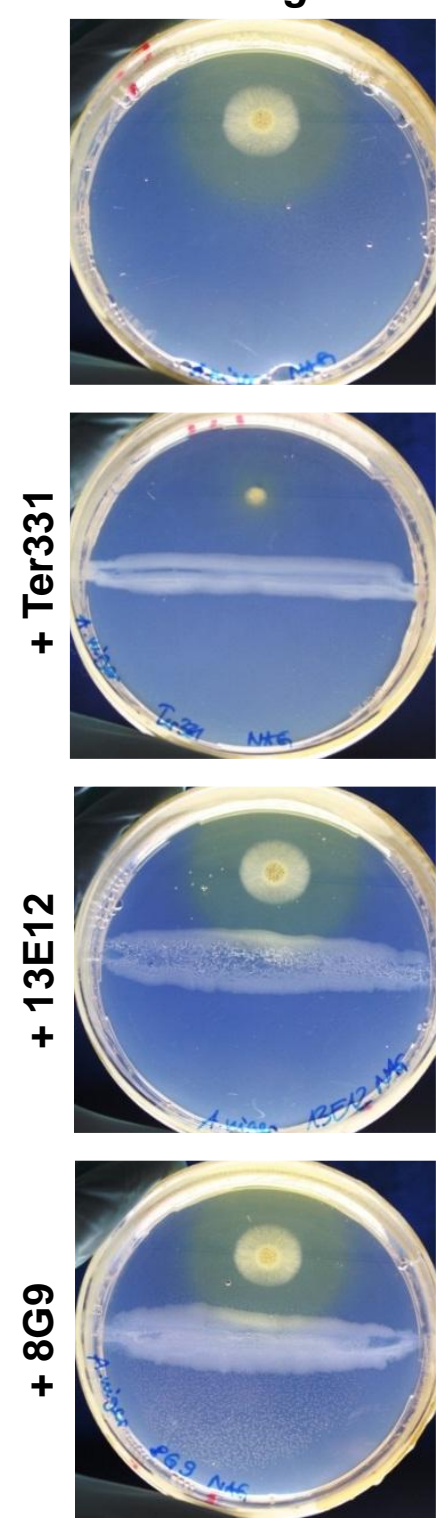

A. versicolor
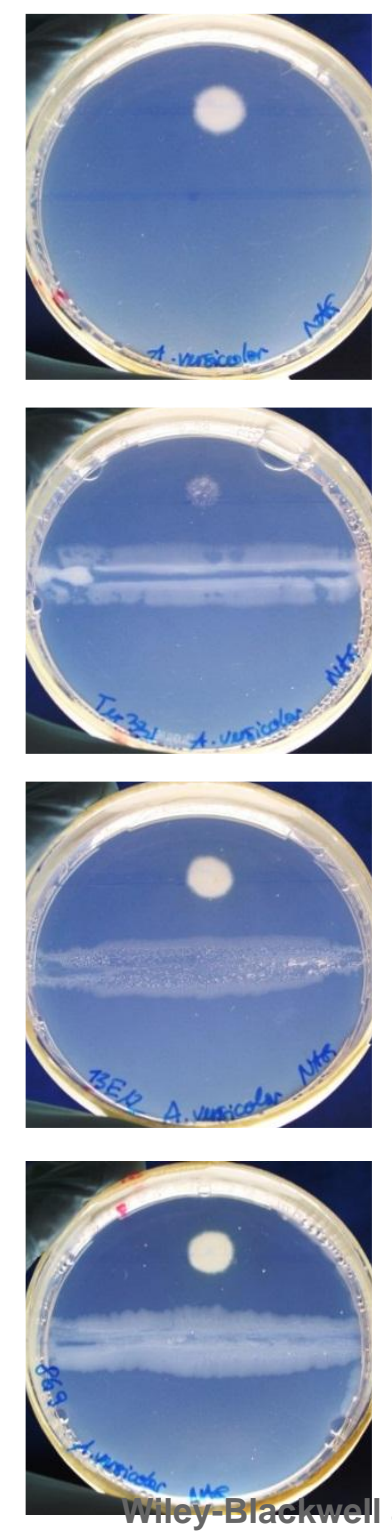

A. westerdijkiae

P. chrysogenum
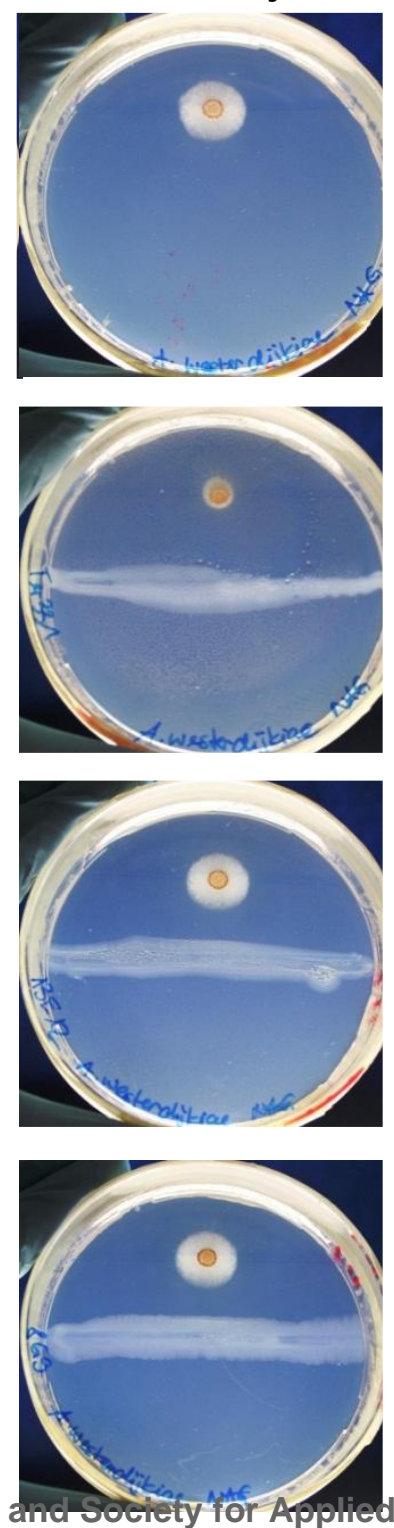

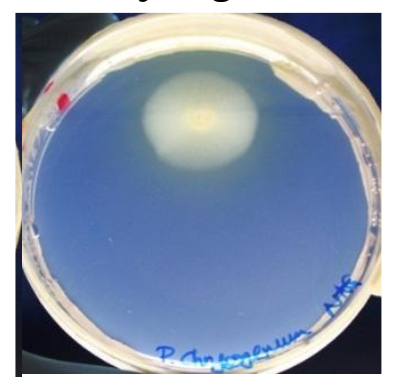

P. glabrum
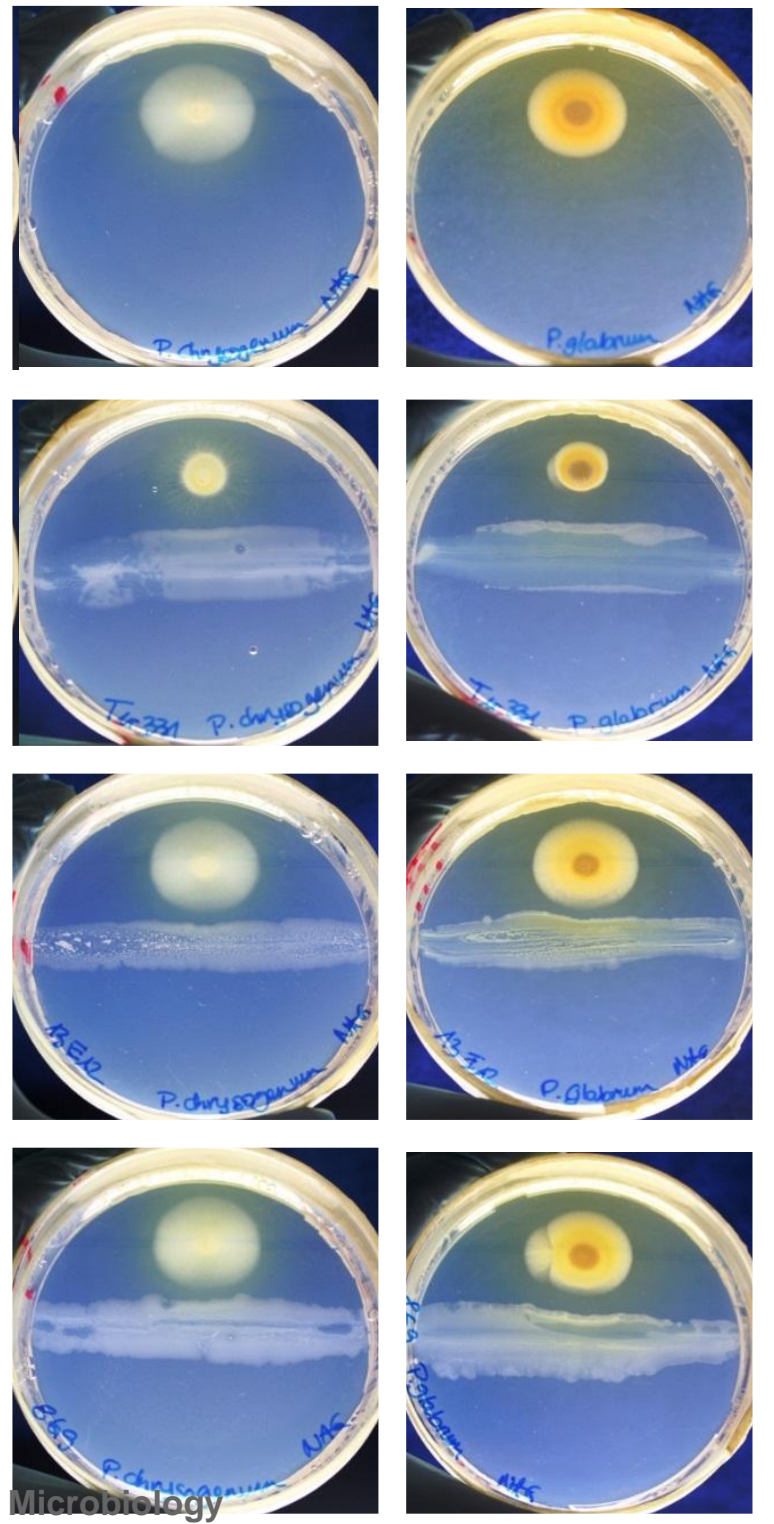


\section{Figure S2}
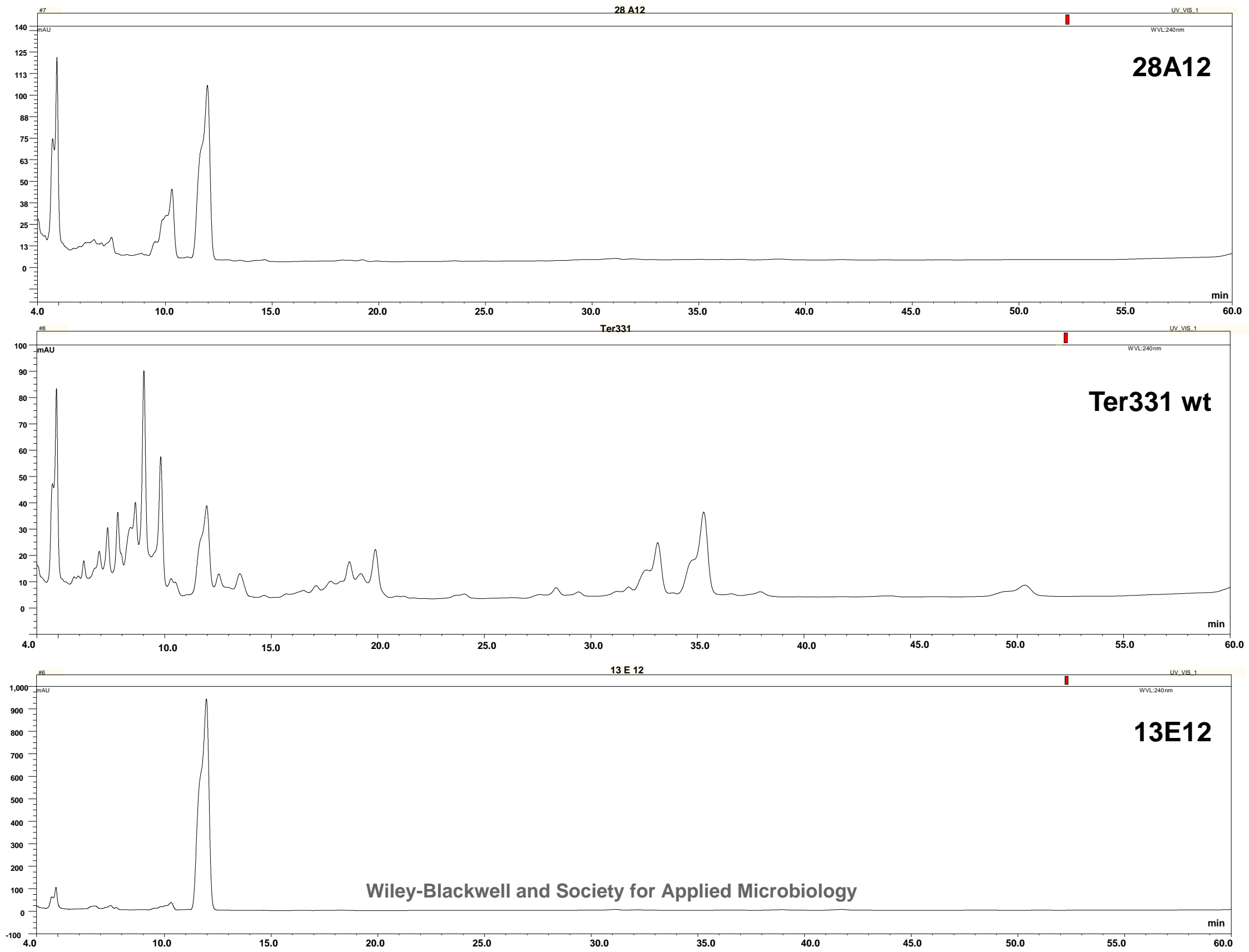